\title{
WAKAF PRODUKTIF DALAM PERSPEKTIF EKONOMI ISLAM
}

\author{
Oleh : Fahmi Medias ${ }^{1}$
}

\begin{abstract}
This article is aimed to oversee the rule and significance of cash waqf in Indonesia as a new social tool to alleviate poverty. Library research is employed to analyze the development of cash waqf in Indonesia. Cash waqf is introduced as a new concept of waqf to solve many social problems in society. In Indonesia it has been legalized by both Islamic scholar and national law so that Muslims have a chance to maximize its utilization. To improve and extend cash waqf functions for social purposes it is important to every waqf organization to develop its human resources capacity, mainly in its professionalism, commitment, and understanding of cash waqf importance for development.
\end{abstract}

Kata kunci: Waqaf tunai, Waqaf produktif, Ekonomi Islam

\section{Pendahuluan}

Di tengah problem sosial masyarakat Indonesia dan tuntutan akan kesejahteraan ekonomi akhir-akhir ini, keberadaan wakaf uang menjadi sangat strategis. Disamping sebagai salah satu aspek ajaran Islam yang berdimensi spiritual, wakaf uang juga merupakan ajaran yang menekankan pentingnya kesejahteraan ekonomi (dimensi sosial) dan kesejahteraan umat. $^{2}$

Namun istilah wakaf uang belum begitu familiar di tengah masyarakat Indonesia, ini bisa dilihat dari pemahaman masyarakat Indonesia yang memandang wakaf hanya sebatas pada pemberian berbentuk barang tidak bergerak, seperti tanah dan bangunan yang diperuntukkan untuk tempat ibadah, kuburan, pondok pesantren, rumah yatim piatu dan pendidikan semata. ${ }^{3}$ Pemanfaatan benda wakaf masih berkisar pada hal-hal yang bersifat fisik, sehingga tidak memberikan dampak ekonomi secara signifikan terhadap kesejahteraan masyarakat. Banyaknya harta benda wakaf yang ada di masyarakat Indonesia belum mampu mengatasi masalah kemiskinan.

Padahal benda yang bergerak, seperti uang misalnya, pada hakikatnya juga merupakan salah satu bentuk instrumen wakaf yang memang diperbolehkan dalam Islam. Saat ini dikalangan masyarakat luas mulai muncul istilah cash waqf (wakaf uang)

1 Alumni Program Studi Ekonomi Islam, Fakultas Ilmu Agama Islam, Universitas Islam Indonesia. Email: fahmi_medias@yahoo.com

${ }^{2}$ Direktorat Pemberdayaan Wakaf dan Direktorat Jenderal Bimbingan Masyarakat Islam, 2008, Paradigma Baru Wakaf di Indonesia, (Jakarta : Februari), hal. 1.

${ }^{3}$ Anonim, 2009, Strategi Pengembangan Wakaf Uang di Indonesia,(Jakarta: Februari), hal 8. 
dipelopori oleh M. A. Mannan, seorang ekonom yang berasal dari Bangladesh. ${ }^{4}$ Wakaf uang dipandang sebagai salah satu solusi yang dapat membuat wakaf menjadi lebih produktif. Apabila wakaf uang mampu dikelola dan diberdayakan oleh suatu lembaga secara profesional, akan sangat membantu dalam mensejahterakan ekonomi umat, memenuhi hak-hak masyarakat, serta mengurangi penderitaan masyarakat.

Pengelolaan wakaf uang secara produktif untuk kesejahteraan masyarakat menjadi tuntutan yang tidak bisa dihindari lagi. Apalagi di saat ini negri Indonesia mengalami krisis ekonomi yang memerlukan partisipasi banyak pihak. ${ }^{5}$ Lahirnya Undang-Undang Republik Indonesia No. 41 tahun 2004 tentang Wakaf diarahkan untuk memberdayakan wakaf yang merupakan salah satu instrumen dalam membangun kehidupan sosial ekonomi umat Islam. Kehadiran Undang-undang wakaf ini menjadi momentum pemberdayaan wakaf secara produktif, sebab di dalamnya terkandung pemahaman yang komprehensif dan pola manajemen pemberdayaan potensi wakaf secara modern.

Undang-Undang Republik Indonesia No. 41 tahun 2004 tentang Wakaf mencakup harta tidak bergerak maupun yang bergerak, termasuk wakaf uang yang penggunaannya sangat luas, tidak terbatas untuk pendirian tempat ibadah dan sosial keagamaan. Formulasi hukum yang demikian, jelas suatu perubahan yang sangat revolusioner dan jika dapat direalisasikan akan memiliki akibat yang berlipat ganda atau multiplier effect, terutama dalam kaitannya dengan pemberdayaan ekonomi umat Islam.

Namun, usaha ke arah itu jelas bukan pekerjaan yang mudah. Umat Islam Indonesia selama ratusan tahun sudah terlanjur mengidentikkan wakaf dengan (dalam bentuk) tanah, dan benda bergerak yang sifatnya bendanya tahan lama. Dengan demikian, Undang-Undang No. 41 tahun 2004 tentang Wakaf diproyeksikan sebagai sarana rekayasa sosial (social engineering), melakukan perubahan-perubahan pemikiran, sikap dan perilaku umat Islam agar senafas dengan semangat UU tersebut. ${ }^{6}$ Salah satu regulasi baru dalam Undang-Undang Wakaf tersebut adalah Wakaf Uang. Makalah ini akan mencoba membahas wakaf produktif tersebut dalam perspektif ekonomi islam dan bagaimana prospeknya dalam pemberdayaan ekonomi umat islam.

\section{Tinjauan Umum Wakaf Produktif}

Secara umum tidak terdapat ayat al-Quran yang menerangkan konsep wakaf secara konkrit tekstual. Wakaf termasuk infaq fi sabilillah, maka dasar yang digunakan para ulama dalam menerangkan konsep wakaf ini didasarkan pada keumuman ayat-ayat al-Quran yang menjelaskan tentang infaq $f i$ sabilillah. Di antara ayat-ayat tersebut antara lain:

${ }^{4}$ Farid Wadjdy, , 2008, Wakaf dan Kesejahteraan Umat (Filantropi Islam yang Hampir Terlupakan), (Yogyakarta : Pustaka Pelajar), hal. 79.

${ }^{5}$ Achmad Djunaidi, 2008, Menuju Era Wakaf Produktif, (Depok : Mumtaz Publishing), hal. 90.

${ }^{6}$ Satjipto Rahardjo, 1986, Hukum dan Masyarakat (Bandung: Angkasa) hlm. 117. 


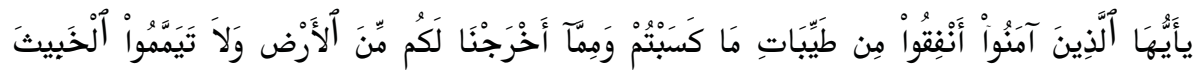

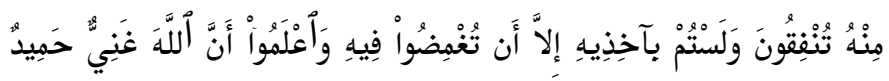

"Hai orang-orang yang beriman, nafkahkanlah (di jalan Allah) sebagian dari hasil usahamu yang baik-baik dan sebagian dari apa yang Kami keluarkan dari bumi untuk kamu. Dan janganlah kamu memilih yang buruk-buruk lalu kamu nafkahkan daripadanya, padahal kamu sendiri tidak mau mengambilnya melainkan dengan memicingkan mata terhadapnya. Dan ketahuilah, bahwa Allah Maha Kaya lagi Maha Terpuji."

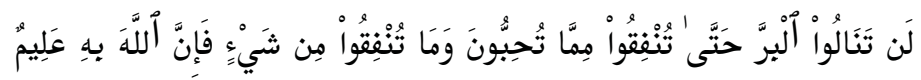

"Kamu sekali-kali tidak sampai kepada kebajikan (yang sempurna) sebelum kamu menafkahkan sebagian dari apa yang kamu cintai. Dan apa saja yang kamu nafkahkan, maka sesungguhnya Allah mengetahuinya"

$$
\text { إذا مات ابن آدم إنقطع عمله إلاّ من ثلاث : صدقة جارية, أو علم ينتفع به, أو ولد صالح يدعو }
$$

"Dari Abu Hurairah r.a. bahwasannya Rasulullah saw bersabda: Apabila manusia meninggal dunia, putuslah pahala semua amalnya, kecuali tiga macam amal yaitu: sedekah jariyah (wakaf), ilmu yang bermanfaat dan anak yang sholeh yang selalu mendo'akan orang tua"'. Para ulama menafsirkan istilah shodaqoh jariyah disini dengan wakaf.

Hadits yang diriwayatkan oleh Muslim dari Ibnu Umar:

$$
\begin{aligned}
& \text { اصاب عمر ارضا بخيبر فأتى النبي صلي الله عليه وسلم يستامره فيها فقال يا رسول اللّ اني } \\
& \text { اصبت ارضا بخيبر لم اصب مالا قط هو انفس عندي منه فما تامرني به؟ فقال رسول الله صلي } \\
& \text { الله عليه وسلم :ان شدُت حبست اصلهاوتصدقت بها .فتصدق بها عمر :انها لا تباع و لا توهب } \\
& \text { ولا تورث .وتصدق بها في الفقراء وفي القربي وفي الرقاب وفي سبيل الله وابن السبيل والضيف لا } \\
& \text { جناح علي من وليها ان يأكل منها بالمعروف ويطعم غير متمول فيه }
\end{aligned}
$$

"Bahwa Umar bin al Khattab r.a. memperoleh tanah di Khaibar, lalu ia datang kepada Nabi S.A.W untuk meminta petunjuk mengenai tanah tersebut. Ia berkata, "Wahai RAsulullah saya memperoleh tanah di Khaibar yang belum

\footnotetext{
${ }^{7}$ Q.S. al-Baqarah (2): 267.

${ }^{8}$ Q.S. Ali Imran (3): 92.

${ }^{9}$ M. Sjarief Sukandi, Tarjamah Bulughul Maram, (Bandung: PT. Al-Maarif), hal. 340
} 
Fahmi Medias: Wakaf Produktif...

pernah saya peroleh harta yang lebih baik bagiku melebihi tanah tersebut; apa perintah engkau kepadaku mengenainya? Nabi S.A.W menjawab: "Jika mau, kamu tahan pokoknya dan kamu sedekabkan hasilnya. Ibnu Umar berkata "Maka, Umar menyedekahkan tanah tersebut, dengan mensyaratkan bahwa tanah itu tidak dijual, tidak dibibahkan, dan tidak diwariskan. Ia menyedekahkan hasilnya kepada fuqara', kerabat, riqab, sabilillah, ibnu sabil, dan tamu. Tidak berdosa atas orang yang mengelolanya untuk memakan dari hasil itu secara ma'ruf dan member makan kepada orang lain tanpa menjadikannya sebagai harta hak milik" 10

Para ulama mazhab syafi'i juga telah membolehkan adanya wakaf uang, ini dijelaskan dalam riwayat Imam Syafi'i yang berbunyi:

$$
\text { وروى ابو ثور عن الشافعي جواز وقفها اى الدنانير والدراهيم }
$$

"Abu Tsaur meriwayatkan dari Imam Syafi'i tentang dibolehkannya wakaf dinar dan dirham (Uang)". ${ }^{11}$

Komisi Fatwa Majelis Ulama Indonesia (MUI) juga membolehkan wakaf uang. Fatwa komisi fatwa MUI itu dikeluarkan pada tanggal 11 Mei 2002. Pada saat itu komisi fatwa MUI juga merumuskan definisi tentang wakaf, yaitu:

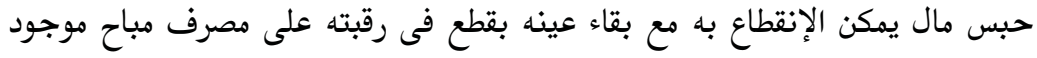

"Menekan harta yang dapat dimanfaatkan tanpa lenyap bendanya atau pokonya. Dengan cara tidak melakukan tindakan hukum terhadap benda tersebut (menjual, memberikan, atau mewariskannya), untuk disalurkan (hasilnya) pada sesuatu yang mubah (tidak) haram yang ada". ${ }^{2}$

Perilaku sejenis wakaf telah dikenal umat manusia sebelum Islam datang. Umat manusia terlepas dari agama dan kepercayaan yang mereka anut sesungguhnya telah mengenal beberapa bentuk praktik pendayagunaan harta benda, yang substansinya tidak jauh berbeda dengan wakaf dalam Islam. Hal ini disebabkan pada dasarnya, umat manusia sudah menyembah Tuhan melalui ritual keagamaan sesuai kepercayaan mereka. Hal inilah yang kemudian menjadi faktor pendorong bagi setiap umat beragama untuk mendirikan bangunan peribadatannya masing-masing. ${ }^{13}$

Jika praktik wakaf telah dikenal sebelum Islam, maka yang membedakannya dengan wakaf dalam Islam adalah bahwa praktik wakaf yang diamalkan masyarakat

${ }^{10}$ Imam Muslim, Sahih Muslim (Bandung: Dahlan).

${ }^{11}$ Al-Mawardi, , 1994, al-Hawi al-Kabir, tahqiq Mahmud Mathraji, (Beirut : Dar al-Fikr, Juz IX), hal. 379.

${ }^{12}$ Keputusan Komisi Fatwa MUI yang dikeluarkan tanggal 11 Mei 2002, yang ditandatangani K.H. Ma'ruf Amin (sebagai ketua) dan Hasanuddin. (sebagai sekretaris).

${ }^{13}$ Direktorat Pemberdayaan Wakaf dan Direktorat Jenderal Bimbingan Masyarakat Islam, 2008, Pedoman Pengelolaan Wakaf Uang, (Jakarta), hal. 4. 
jahiliyah dilakukan semata-mata hanya untuk mencari prestise (kebanggaan). Sedangkan dalam Islam bertujuan untuk mencari ridla Allah dan sebagai sarana mendekatkan diri kepada-Nya.

Dalam sejarah Islam, wakaf dikenal sejak masa Rasulullah SAW karena wakaf disyariatkan pada tahun kedua Hijriyah. ${ }^{14}$ Ada dua pendapat yang berkembang di kalangan ahli yurisprudensi Islam (fuqaha) tentang siapa yang pertama kali melaksanakan syariat wakaf. Menurut sebagian pendapat ulama mengatakan bahwa yang pertama kali melaksanakan wakaf adalah Rasulullah SAW yaitu wakaf tanah milik Nabi SAW untuk dibangun masjid. Sebagian ulama menyatakan bahwa yang pertama kali melaksanakan syariat wakaf adalah Umar bin Khatab. Pendapat ini berdasarkan hadits yang diriwayatkan Ibnu Umar ra, sebagaimana telah dikemukakan di atas.

Praktek wakaf juga berkembang luas pada masa dinasti Umayyah dan dinasti Abbasiyah dan dinasti sesudahnya, banyak orang berduyun-duyun untuk melaksanakan wakaf, dan wakaf tidak hanya untuk orang-orang fakir dan miskin saja, tetapi wakaf menjadi modal untuk membangun lembaga pendidikan, membangun perpustakaan dan membayar gaji para statnya, gaji para guru dan beasiswa untuk para siswa dan mahasiswa. Antusiasme masyarakat kepada pelaksanaan wakaf telah menarik perhatian negara untuk mengatur pengelolaan wakaf sebagai sektor untuk membangun solidaritas sosial dan ekonomi masyarakat. ${ }^{15}$

Di Indonesia, kegiatan wakaf dikenal seiring dengan perkembangan dakwah Islam di Indonesia. Di samping melakukan dakwah Islam, para ulama juga sekaligus memperkenalkan ajaran wakaf. Hal ini terbukti dari banyaknya masjid-masjid yang bersejarah dibangun di atas tanah wakaf. Ajaran wakaf ini terus berkembang di Indonesia, baik pada masa dakwah pra kolonial, masa kolonial, maupun pasca kolonial pada masa Indonesia merdeka.

Hal ini terlihat dari kenyataan bahwa lembaga wakaf yang berasal dari agama Islam ini telah diterima (diresepsi) menjadi hukum adat bangsa Indonesia sendiri. Masa pemerintahan kolonial merupakan momentum kegiatan wakaf. Karena pada masa itu, perkembangan organisasi keagamaan, sekolah, madrasah, pondok pesantren, masjid, semuanya merupakan swadaya dan berdiri di atas tanah wakaf. Namun, perkembangan wakaf kemudian hari tak mengalami perubahan yang berarti. Kegiatan wakaf dilakukan terbatas untuk kegiatan keagamaan, seperti pembangunan masjid, mushalla, langgar, madrasah, perkuburan, sehingga kegiatan wakaf di Indonesia kurang bermanfaat secara ekonomis bagi rakyat banyak.

Walaupun beberapa aturan telah dibuat oleh pemerintah terkait dengan mekanisme wakaf, seperti PP Nomor 28 Tahun 1977 Tentang Perwakafan Tanah Milik, akan tetapi PP ini hanya mengatur wakaf pertanahan saja. Ini berarti tak jauh beda dengan model wakaf pada periode awal, identik dengan wakaf tanah, dan

\footnotetext{
${ }^{14}$ Ibid, hal. 6.

${ }^{15}$ Ibid, hal. 8.
} 
Fahmi Medias: Wakaf Produktif...

kegunaannya pun terbatas pada kegiatan sosial keagamaan, seperti masjid, kuburan, madrasah, dan lain-lain.

Karena minimnya regulasi yang mengatur tentang perwakafan, maka tidaklah heran jika perkembangan wakaf di Indonesia mengalami stagnasi. Stagnasi perkembangan wakaf di Indonesia mulai mengalami dinamisasi ketika pada tahun 2001, beberapa praktisi ekonomi Islam mulai mengusung paradigma baru ke tengah masyarakat mengenai konsep baru pengelolaan wakaf uang untuk peningkatan kesejahteraan umat. Ternyata konsep tersebut menarik dan mampu memberikan energi untuk menggerakkan kemandegan perkembangan wakaf. Kemudian pada tahun 2002, Majelis Ulama Indonesia (MUI) menyambut konsep tersebut dengan mengeluarkan fatwa yang membolehkan wakaf uang (waqf al-nuqud).

Fatwa MUI tersebut kemudian diperkuat oleh hadirnya Undang-Undang No. 41 Tahun 2004 Tentang Wakaf yang menyebutkan bahwa wakaf tidak hanya benda tidak bererak, tetapi juga dapat berupa benda bergerak, seperti uang. Selain itu, diatur pula kebijakan perwakafan di Indonesia, mulai dari pembentukan nadzir sampai dengan pengelolaan harta wakaf. Untuk dapat menjalankan fungsinya, Undang-Undang ini masih memerlukan perangkat lain yaitu Peraturan Pemerintah dan Peraturan Menteri Agama tentang Wakaf Uang yang akan menjadi juklak dalam implementasinya, serta adanya Badan Wakaf Indonesia (BWI) yang akan berfungsi sebagai sentral nadzir wakaf. Setelah melalui proses panjang, pada penghujung tahun 2006 terbitlah Peraturan Pemerintah No. 42/2006 Tentang Pelaksanaan Undang-Undang Wakaf. Setelah itu, pada juli 2007 keluar Keputusan Presiden Republik Indonesia nomor 75/M tahun 2007 yang memutuskan dan mengangkat keanggotaan BWI periode 2007$2010 .{ }^{16}$

Selain hal itu, Majelis Ulama Indonesia (MUI) telah mengeluarkan Fatwanya tentang Wakaf Uang pada tanggal 11 Mei 2002, yang menyatakan bahwa : ${ }^{17}$

1. Wakaf Uang (Cash Wakaf/Waqf al-Nuqud) adalah wakaf yang dilakukan seseorang, kelompok orang, lembaga atau badan hokum dalam bentuk uang.

2. Termasuk ke dalam pengertian uang adalah surat berharga,

3. Wakaf Uang hukumnya jawaz (boleh);

4. Wakaf Uang hanya boleh disalurkan dan digunakan untuk hal-hal yang diperbolehkan secara syar'i;

5. Nilai pokok Wakaf Uang harus dijamin kelestariannya, tidak boleh dijual, dihibahkan dan/atau diwariskan.

Lahirnya Undang-Undang No. 41 Tahun 2004 Tentang Wakaf, Fatawa Majelis Ulama Indonesia berikut peraturan turunannya merupakan titik tolak

${ }_{16}$ Tholhah Hasan (2009), "Perkembangan Kebijakan Wakaf di Indonesia”, dalam Republika, Rabu, 22 April 2009, accessed 3 Juli 2009.

${ }^{17}$ Majelis Ulama Indonesia, Fatwa Tentang Wakaf Uang Tahun 2002. 
peningkatan pemberdayaan potensi wakaf di Indonesia ke arah yang lebih produktif dalam bingkai fiqh Indonesia.

Undang-undang Nomor 41 Tahun 2004 Tentang Wakaf ini juga menjadi momentum pemberdayaan wakaf secara produktif sebab di dalamnya terkandung pemahaman yang komprehensif dan pola manajemen pemberdayaan potensi wakaf secara modern. Dalam undang-undang wakaf yang baru ini konsep wakaf mengandug dimensi yang sangat luas. Ia mencakup harta tidak bergerak, maupun yang bergerak, termasuk wakaf uang yang penggunaannya sangat luas, tidak terbatas untuk pendirian tempat ibadah dan sosial keagamaan.

Berdasarkan uraian di atas, dengan telah diaturnya wakaf dalam bentuk undang-undang di Indonesia, sektor wakaf dapat lebih difungsikan ke arah peningkatan kesejahteraan sosial ekonomi umat. Dari sini nampak jelas bagaimana kepentingan kesejahteraan sosial sangat kuat mempengaruhi proses regulasi di bidang perwakafan. Semangat pemberdayaan potensi wakaf secara produktif dan profesional yang dikumadangkan undang-undang wakaf adalah untuk kepentingan kesejahteraan umat manusia di bidang ekonomi, pendidikan, kesehatan, maupun bidang sosial keagamaan lainnya.

\section{Wakaf Produktif Di Indonesia}

Wakaf uang membuka peluang yang unik untuk menciptakan investasi guna memberikan pelayanan keagamaan, layanan pendidikan, dan layanan sosial. Tabungan orang-orang kaya dapat dimanfaatkan dengan menukarkannya dengan Cash-Waqf Certificate. Hasil pengembangan wakaf yang diperoleh dari sertifikat tersebut dapat dimanfaatkan untuk tujuan-tujuan yang bermacam-macam seperti tujuan-tujuan wakaf itu sendiri. Kegunaan lain dari Cash Waqf Certificate adalah bahwa dia dapat mengubah kebiasaan lama di mana kesempatan wakaf seolah-olah hanya untuk orang-orang kaya saja.

Secara konseptual, wakaf uang mempunyai peluang yang unik untuk menciptakan investasi di bidang keagamaan, pendidikan, dan layanan sosial. Tabungan dari masyarakat yang mempunyai penghasilan menengah ke atas dapat dimanfaatkan melalui penukaran dengan Sertifikat Wakaf Uang (SWT), sedangkan pendapatan yang diperoleh dari pengelolaan wakaf uang dapat dibelanjakan untuk berbagai tujuan, di antaranya untuk pemeliharaan dan pengelolaan tanah wakaf. Mustofa Edwin Nasution memaparkan cara memanfaatkan potensi SWT yang digali di Indonesia, yakni:

1. Lingkup sasaran pemberi wakaf uang bisa menjadi sangat luas dibanding wakaf biasa.

2. Sertifikat wakaf uang dapat dibuat berbagai macam pecahan, yang disesuaikan dengan segmen umat islam yang memungkinkan untuk membangkitkan semangat beramal jariyah, misalnya rp. 10.000,- dan rp. 25.000,- 
Fahmi Medias: Wakaf Produktif...

Mustafa Edwin Nasution pernah melakukan asumsi bahwa jumlah penduduk Muslim kelas menengah di Indonesia sebanyak 10 juta jiwa dengan rata-rata penghasilan perbulan antara $\mathrm{Rp} 500.000,00$ (lima ratus ribu rupiah) - Rp 10.000.000,00 (sepuluh juta rupiah) maka dapat dibuat perhitungan sebagai berikut.

Tabel. 2.1 Tabel Potensi Wakaf Uang di Indonesia ${ }^{18}$

\begin{tabular}{|l|l|l|l|l|}
\hline $\begin{array}{l}\text { Tingkat Penghasilan / } \\
\text { bulan }\end{array}$ & $\begin{array}{l}\text { Jumlah } \\
\text { Muslim }\end{array}$ & $\begin{array}{l}\text { Tarif } \\
\text { Wakaf/bulan }\end{array}$ & $\begin{array}{l}\text { Potensi Wakaf } \\
\text { Uang / bulan }\end{array}$ & $\begin{array}{l}\text { Potensi Wakaf } \\
\text { Uang / tahun }\end{array}$ \\
\hline Rp 500.000 & 4 juta & Rp 5000,- & Rp 20 Milyar & Rp 240 Milyar \\
\hline Rp 1 juta -Rp 2 juta & 3 juta & Rp 10.000 & Rp 30 Milyar & Rp 360 Milyar \\
\hline Rp 2 juta - Rp 5 juta & 2 juta & Rp 50.000 & Rp 100 Milyar & Rp 1,2 Triliun \\
\hline Rp 5 juta- Rp 10 juta & 1 juta & Rp 100.000 & Rp 100 Milyar & Rp 1,2 Triliun \\
\hline Total & & & & Rp 3 Triliun \\
\hline
\end{tabular}

Adapun penjelasan dari tabel di atas adalah:

1. Apabila umat Islam yang berpenghasilan Rp500.000,00 sejumlah 4 juta orang dan setiap tahun masing-masing berwakaf sebanyak Rp60.000,00 maka setiap tahun terkumpul Rp240.000.000.000,00.

2. Apabila umat yang berpenghasilan Rp1.000.000,00 - Rp2.000.000,00 sejumlah 3 juta orang dan setiap tahun masing-masing berwakaf Rp120.000,00 maka setiap tahun terkumpul dana sebanyak Rp360.000.000.000,00.

3. Apabila umat yang berpenghasilan Rp2.000.000,00 - Rp5.000.000,00 sejumlah 2 juta orang dan setiap tahun masing-masing berwakaf Rp600.000,00 maka setiap tahun terkumpul dana sebanyak Rp1.200.000.000.000,00.

4. Apabila ummat yang berpenghasilan Rp5.000.000,00 - Rp10.000.000,00 sejumlah 1 juta orang dan setiap tahun masing-masing berwakaf Rp1.200.000,00 maka setiap tahun terkumpul dana sebanyak Rp1,200.000.000.000,00.

${ }^{18}$ Mustafa Edwin Nasution dan Uswatun Hasanah (Editor), 2005, Wakaf Uang Inovasi Finansial Islam, Peluang dan Tantangan dalam Mewujudkan Kesejahteraan Umat (Jakarta: PKTTI-UI), hal. 4344. 
Fahmi Medias: Wakaf Produktif...

Dengan demikian wakaf yang terkumpul selama satu tahun sejumlah Rp3.000.000.000.000,00. Berdasarkan contoh perhitungan di atas maka terlihat bahwa keberhasilan lembaga untuk memobilisasi dana wakaf akan sangat menentukan manfaat keberadaan lembaga wakaf, yang menjadi masalah, uang tersebut tidak dapat langsung diberikan kepada mauquf 'alaih, tetapi nadzir harus mengelola dan mengembangkannya terlebih dahulu. Yang harus disampaikan kepada mauquf 'alaih adalah hasil investasi dana Rp. 3.000.000.000.000,00 tersebut, sedangkan uang wakafnya sendiri tidak boleh berkurang sedikit pun.

Potensi dari wakaf uang sangat besar jika mampu dikelola secara baik. Terutama jika dana itu diserahkan kepada pengelola profesional dan diinvestasikan di sektor yang produktif sehingga dana tersebut dapat digunakan untuk kegiatan ekonomi produktif dalam rangka membantu kaum dhuafa dan kepentingan ummat. Dengan demikian jumlah wakaf uang tidak akan berkurang, akan tetapi bertambah dan terus. Jika dana wakaf uang ditipkan di Bank Syari'ah dan setiap tahun diberikan bagi hasil sebesar $9 \%$, maka pada akhir tahun akan diperoleh dana hasil investasi sebesar Rp. 270.000.000.000. ${ }^{19}$

Sebagai tindak lanjut dari lahirnya Undang-Undang No 41 Tahun 2004 tentang wakaf, saat ini di Indonesia banyak perbankan syariah dan lembaga pengelola wakaf meluncurkan produk dan fasilitas yang menghimpun dana wakaf uang dari masyarakat. Seperti Baitul Mal Muamalat yang meluncurkan Waqf Uang Muamalat, Dompet Dhuafa Republika yang meluncurkan Tabung Wakaf Indonesia, dan lembaga wakaf nasional yang dibentuk berdasarkan Undang-Undang tentang Wakaf pada tahun 2007 yaitu Badan Wakaf Indonesia.

Lembaga-lembaga di atas telah banyak membuat program untuk mewujudkan keadilan sosial yang dihasilkan dari investasi dana wakaf yang dihimpun dari masyarakat, seperti pembentukan rumah sakit, sekolah, dan kampung peternakan yang berpotensi mengembangkan wakaf uang untuk membangun kesejahteraan masyarakat secara luas dan berkesinambungan. Program-program yang telah dicanangkan oleh lembaga wakaf di Indonesia dengan mengelola dana wakaf uang dalam bentuk ini adalah dalam upaya agar harta wakaf lebih berkembang manfaat ekonomi dan sosialnya. Contohnya saja, penghimpunan dan pengelolaan dana wakaf uang pada Tabung Wakaf Indonesia yang hasil pengelolaannya disalurkan pada bidang pendidikan, ekonomi, dan bidang sosial. ${ }^{20}$ Selain itu, hasil pengelolaan yang di peroleh oleh Badan Wakaf Indonesia disalurkan pada bidang pendidikan dan kesehatan. ${ }^{21}$

${ }^{19}$ Direktorat Pemberdayaan Wakaf dan Direktorat Jendetal Bimbingan Masyarakat Islam, 2008, Pedoman Pengelolaan Wakaf Uang, (Jakarta), hal. 72

${ }^{20}$ Tabung Wakaf Indonesia, Laporan Keuangan Tahun 2001-2009

${ }^{21}$ Badan Wakaf Indonesia, Laporan Wakaf Uang Tahun 2010. 
Fahmi Medias: Wakaf Produktif...

Dari pemaparan di atas, terlihat bahwa sudah banyak lembaga-lembaga wakaf di Indonesia yang mencoba untuk mengelola wakaf uang secara produktif yang sesuai dengan peraturan maupun perundang-undangan tentang wakaf.

\section{Wakaf Produktif Perspektif Ekonomi Islam}

Salah satu lembaga ekonomi islam yang sangat berperan dalam pemberdayaan ekonomi umat adalah wakaf. Dalam sejarah, wakaf telah memerankan peran penting dalam pengembangan sosial, ekonomi, dan budaya masyarakat. Hal-hal yang paling menonjol dari lembaga wakaf adalah peranannya dalam membiayai berbagai pendidikan Islam dan kesehatan. Sebagai contoh misalnya di Mesir, Saudi Arabia, Turki dan beberapa Negara lainnya pembangunan dan berbagai sarana dan prasarana pendidikan dan kesehatan dibiayai dari hasil pengembangan wakaf. Kesinambungan manfaat hasil wakaf dimungkinkan oleh berlakunya wakaf produktif yang didirikan untuk menopang berbagai kegiatan sosial dan keagamaan. Wakaf Produktif pada umumnya berupa tanah pertanian atau perkebunan, gedung-gedung komersial, dikelola sedemikian rupa sehingga mendatangkan keuntungan yang sebagian hasilnya dipergunakan untuk membiayai berbagai kegiatan tersebut. Sehingga dengan demikian harta wakaf benarbenar menjadi sumber dana dari masyarkat untuk masyarakat. ${ }^{22}$

Salah satu bentuk wakaf produktif dalam ijtihad ulama masa kini adalah bentuk wakaf uang memang belum lama dikenal di Indonesia. Padahal wakaf uang tersebut sebenarnya sudah cukup lama dikenal di dunia Islam, yakni sejak zaman kemenangan dinasti mamluk, para ahli fikih memperdebatkan boleh atau tidaknya uang, diwakafkan. Ada sebagian ulama yang membolehkan wakaf uang, dan sebagian ulama melarangnya, dan masing-masing mempunyai alasan yang memadai. Meskipun wakaf uang sudah dikenal pada masa Imam Mazhab, namun wakaf uang baru akhirakhir ini mendapat perhatian para ilmuan dan menjadi bahan kajian intensif. Di berbagai Negara, Wakaf Uang sudah lama menjadi kajian, dan bahkan sudah dipraktekkan serta diatur dalam peraturan perundang-undangan. Yang menjadi masalah di berbagai tempat baik di Indonesia maupun di Negara lain adalah pengelolaannya, tidak jarang wakaf dikelola dengan manajemen yang kurang bagus sehingga dapat mengakibatkan wakaf tersebut berkurang atau hilang. Padahal, jika wakaf uang ini diatur, dikelola, dan dikembangkan dengan baik akan membawa dampak yang begitu besar dalam masyarakat. ${ }^{23}$

Perkembangan ekonomi dan pembangunan yang mengacu timbulnya gagasan adanya wakaf uang diantaranya karena berkembangangnya sistem perekonomian Islam. Sistem ekonomi dalam Islam tidak hanya terkait dengan masalah ekonomi abadi

${ }^{22}$ Muhammad Yusuf, 2009, Pemberdayaan Wakaf Produktif Untuk Pemberdayaan Ekonomi Umat, (Semarang: Badan Wakaf Nusantara).

${ }^{23}$ Direktorat Pemberdayaan Wakaf dan Direktorat Jenderal Bimbingan Masyarakat Islam, , 2008, Pedoman Pengelolaan Wakaf Uang, (Jakarta: Maret), hal 93. 
manusia, melainkan juga terkait dengan anjuran Ilahi sebagaimana termaktub dalam Al-Qur'an dan Sunnah. Selain itu sistem ekonomi Islam juga mengacu pada peningkatan output dari setiap jam kerja yang dilakukan. ${ }^{24}$

Dalam sistem ekonomi Islam, wakaf uang belum banyak dieksplorasi ssemaksimal mungkin, padahal wakaf uang sangat berpotensi untuk pemberdayaan ekonomi umat Islam. Karena itu institusi wakaf uang menjadi sangat penting untuk dikembangkan. Meskipun dalam sejarah Islam, wakaf telah memainkan peran yang sangat penting dalam pembangunan masyarakat muslim, namun kita juga menjumpai berbagai kenyataan bahwa pengelolaan wakaf selain memperlihatkan berbagai kemajuan yang mengagumkan, tapi juga memperlihatkan berbagai penyelewengan. Salah urus seringkali terjadi. Oleh karenanya, strategi pengelolaan yang baik perlu diciptakan untuk mencapai tujuan di adakannya wakaf. Wakaf hendaknya dikelola dengan baik dan diinvestasikan ke dalam berbagai jenis investasi, khususnya kepada investasi riil yang bersifat produktif yang dapat menghasilkan keuntungan sehingga hasilnya dapat dimanfaatkan untuk kepentingan masyarakat banyak. Pengelolaan wakaf diserahkan kepada nadzir, baik dari pemerintah maupun masyarakat. ${ }^{25}$

Pengelolaan dana wakaf uang sebagai alat untuk investasi menjadi menarik, karena tujuan utama diinvestasikannya dana wakaf adalah untuk mengoptimalkan fungsi harta wakaf sebagai prasarana untuk meningkatkan kualitas hidup dan kehidupan sumber daya insani. ${ }^{26} \mathrm{Hal}$ inilah yang diharapkan mampu meningkatkan keharmonisan antara masyarakat kaya dan masyarakat miskin. Isu kemashlahatan sosial yang diusulkan dalam wacana wakaf uang memunculkan akar dan subtansi masalah sosial, berupa keadilan ekonomi yang ternyata gagal dimanefestasikan oleh teori pembangunan Kapitalis dan Marxis. Gagasan wakaf uang dipopulerkan kembali melalui pembentukan Social Investment Bank Limited (SIBL) di Bangladesh yang dikemas dalam mekanisme instrument Cash Waqf Certificate telah memberikan kombinasi alternatif solusi mengatasi krisis kesejahteraan yang ditawarkan Umer Chapra dan M.A. Mannan. ${ }^{27}$

Wakaf uang sebagai instrument finansial, keuangan sosial dan perbankan sosial, menurut M. A. Mannan memang merupakan suatu produk baru dalam sejarah perekonomian Islam. Instrument financial yang dikenal dalam perekonomian Islam selama ini berkisar pada murabahah dan musyarakah. Selain itu, umat Islam mengenal konsep wakaf sebagai sumbangan berupa asset tetap oleh seorang muslim dengan tujuan murni ketakwaan. Munculnya gagasan wakaf uang memang mengejutkan karena berlawanan dengan persepsi umat islam yang terbentuk bertahun-tahun lamanya.

${ }^{24}$ Ibid, hal. 35.

${ }^{25}$ Muhammad Syafi'i Antonio, 2002, Bank Syari'ah sebagai Pengelola Dana Wakaf (Makalah Workshop Internasional, "Pemberdayaan Ekonomi Umat Melalui Wakaf Produktif", di Wisma Haji Batam, 7-8 Januari), hal. 4.

${ }^{26}$ Ibid, hal. 40.

${ }^{27}$ Direktorat Jenderal Bimas Islam dan Penyelenggaraan Haji, 2003, Fiqh Wakaf, hal. 90 
Fahmi Medias: Wakaf Produktif...

Wakaf uang bukan merupakan asset tetap yang berbentuk benda tak bergerak seperti tanah, melainkan aset lancar. ${ }^{28}$

Oleh karena itu sangat tepat bila penyaluran dana dalam bentuk pembiayaan produktif ke sektor riil dimobilisir yang salah satunya adalah dengan memberikan pembiayaan mikro melalui mekanisme kontrak investasi kolektif (KIK) semacam reksadana syari'ah yang dihimpun Sertifikat Wakaf Uang (SWT) kepada masyarakat menengah dan kecil agar memiliki peluang usaha dan sedikit demi sedikit bangkit dari kemiskinan dan keterpurukan akibat krisis berkepanjangan. Pemberian skim pembiayaan mikro ini cukup mendidik ibarat memberi kail bukan hanya ikan kepada rakyat dan diharapkan dapat menciptakan kemandirian. Porsi bagi hasil untuk fund manager setelah dikurang biaya oprasional dapat disalurkan untuk kebutuhan konsumtif dalam menunjang kesejahteraan kaum fuqara melalui wasiat wakif (pemegang SWT) ataupun tanpa wasiatnya.

Di tilik dari tujuan dan kontribusi yang dapat diberikan oleh institusi wakaf uang, maka keberadaan wakaf uang di Indonesia menjadi sangat krusial. Setidaknya ada beberapa hal yang mengakibatkan pentingnya pemberdayaan wakaf di Indonesia:

1. Angka kemiskinan di Indonesia masih tinggi, yang perlu mendapat perhatian dan langkah-langkah yang konkrit.

2. Kesenjangan yang tinggi antara penduduk kaya dengan penduduk miskin

3. Indonesia memiliki jumlah penduduk muslim terbesar, sehingga wakaf memiliki potensi yang besar untuk dikembangkan

4. Sejumlah bencana yang terjadi, mengakibatkan terjadinya defisit APBN, sehingga diperlukan kemandirian masyarakat dalam pengadaan public goods. ${ }^{29}$

Meski demikian, bukan sesuatu yang mudah untuk dapat menyelesaikan sejumlah masalah dalam perekonomian nasional. Butuh keseriusan, komitmen dan juga kerja keras untuk dapat menyelesaikannya. Pengembangan wakaf uang memiliki nilai ekonomi yang strategis. Dengan dikembangkannya wakaf uang, maka akan didapat sejumlah keunggulan, di antaranya adalah sebagai berikut:

1. Wakaf uang jumlahnya bisa bervariasi sehingga seseorang yang memiliki dana terbatas sudah bisa mulai memberikan dana wakafnya tanpa harus menunggu menjadi orang kaya atau tuan tanah terlebih dahulu, sehingga dengan program wakaf uang akan memudahkan si pemberi wakaf atau wakif untuk melakukan ibadah wakaf.

${ }^{28}$ Direktorat Pemberdayaan Wakaf dan Direktorat Jenderal Bimbingan Masyarakat Islam, 2008, Pedoman Pengelolaan Wakaf Uang, (Jakarta), hal. 32.

${ }^{29}$ Agustianto, Wakaf Uang dan Peningkatan Kesejabteraan Umat (Artikel Zona Ekonomi Islam), di publikasikan pada Agustus, 2010. 
Fahmi Medias: Wakaf Produktif...

2. Melalui wakaf uang, aset-aset wakaf yang berupa tanah-tanah kosong bisa mulai dimanfaatkan dengan pembangunan gedung atau diolah untuk lahan pertanian.

3. Dana wakaf uang juga bisa membantu sebagian lembaga-lembaga pendidikan Islam yang cash flow-nya kembang-kempis dan menggaji civitas akademika ala kadarnya.

4. Pada gilirannya, insya Allah, umat Islam dapat lebih mandiri dalam mengembangkan dunia pendidikan tanpa harus terlalu tergantung pada anggaran pendidikan negara yang memang semakin lama semakin terbatas.

5. Dana waqaf uang bisa memberdayakan usaha kecil yang masih dominan di negeri ini (99,9 \% pengusaha di Indonesia adalah usaha kecil). Dana yang terkumpul dapat disalurkan kepada para pengusaha tersebut dan bagi hasilnya digunakan untuk kepentingan sosial, dsb. ${ }^{30}$

6. Dana waqaf uang dapat membantu perkembangan bank-bank syari'ah, Keunggulan dana waqaf, selain bersifat abadi atau jangka panjang, dana waqaf adalah dana termurah yang seharusnya menjadi incaran bank-bank syari'ah.

Berbicara tentang produktivitas dari wakaf uang dalam perspektif ekonomi Islam, maka seharusnya pengelolaan wakaf uang yang dilakukan oleh lembaga-lembaga wakaf haruslah mengarah pada pemenuhan kesejahteraan masyarakat Indonesia yaitu pemenuhan kesejahteraan dalam bidang ekonomi, pendidikan, kesehatan, pelayanan sosial, dan pengembangan usaha kecil dan menengah. ${ }^{31}$ Pada prinsipnya, dalam rangka mencapai tujuan dan fungsi wakaf agar lebih produktif, harta benda wakaf hanya dapat diperuntukan bagi:

1. Sarana dan kegiatan ibadah;

2. Sarana dan kegiatan pendidikan serta kesehatan;

3. Bantuan kepada fakir miskin, anak terlantar, yatim piatu, bea siswa;

4. Kemajuan dan peningkatan ekonomi umat; dan/atau

5. Kemajuan kesejahteraan umum lainnya yang tidak bertentangan dengan syari'ah dan peraturan perundang-undangan. ${ }^{32}$

Menurut Uswatun Hasanah, wakaf uang dikatakan produktif jika dapat menghasilkan dana yang bermanfaat bagi kesejahteraan sosial maka benda wakaf harus dikelola secara produktif oleh nadzir (pengelola) yang profesional. Perlu digaris bawahi, uang tersebut tidak dapat langsung diberikan kepada mauquf 'alaih (penerima wakaf), tetapi nadzir harus mengelola dan mengembangkannya terlebih dahulu secara produktif melalui Undang-Undang Nomor 41 Tahun 2004 tentang wakaf, yang harus disampaikan kepada mauquf 'alaih adalah hasil investasi dana wakaf, sedangkan uang wakafnya sendiri tidak boleh berkurang sedikit pun. Karena itu, nadzir selain memenuhi syarat-syarat yang disebutkan dalam Pasal 10 ayat (1) Undang-undang

\footnotetext{
${ }^{30}$ Ibid

${ }^{31}$ Ibid, hal. 72.

${ }^{32} \mathrm{Ibid}$, pasal 22.
} 
Fahmi Medias: Wakaf Produktif...

tentang Wakaf, harus ditambah syarat-syarat lain yang menunjang tugas dan tanggungjawabnya dalam melakukan investasi uang yang diwakafkan. ${ }^{33}$

Selain itu dalam sistem Ekonomi Islam, strategi pengelolaan yang baik perlu diciptakan untuk mencapai tujuan di adakannya wakaf. Wakaf hendaknya dikelola dengan baik dan diinvestasikan ke dalam berbagai jenis investasi, sehingga hasilnya dapat dimanfaatkan untuk kepentingan ekonomi masyarakat banyak.

Wakaf uang sebagai instrument finansial, keuangan sosial dan perbankan sosial, menurut M. A. Mannan memang merupakan suatu produk baru dalam sejarah perekonomian Islam. Instrument financial yang dikenal dalam perekonomian Islam selama ini berkisar pada murabahah dan musyarakah. Selain itu, umat Islam mengenal konsep wakaf sebagai sumbangan berupa asset tetap oleh seorang muslim dengan tujuan murni ketakwaan. Munculnya gagasan wakaf uang memang mengejutkan karena berlawanan dengan persepsi umat islam yang terbentuk bertahun-tahun lamanya. Wakaf uang bukan merupakan asset tetap yang berbentuk benda tak bergerak seperti tanah, melainkan aset lancar. ${ }^{34}$

\section{Penutup}

Dimasukkannya wakaf uang dalam perundangan-undangan Republik Indonesia melalui Undang-Undang No 41 tahun 2004, merupakan angin segar dan peluang baru bagi umat Islam Indonesia untuk mengelola dan mengembangkan suatu potensi dana umat yang cukup besar dengan produktif dan profesional dalam meningkatkan kesejahteraan ekonomi kaum muslimin dan melepaskan umat Islam dari kemiskinan. Bahkan dimungkinkan, wakaf uang bisa menjadi jalan alternatif untuk melepas ketergantungan bangsa ini dari lembaga-lembaga kreditor multilateral sekaligus menstimulasi pertumbuhan ekonomi Indonesia khususnya ekonomi Islam. Sebagai negara yang berpenduduk mayoritas muslim, eksistensi instrumen syariah ini memilki prospek yang baik dan cerah serta akan sangat diterima oleh masyarakat Indonesia sehingga wakaf uang diperkirakan akan memberikan kontribusi besar bagi percepatan pembangunan di Indonesia.

Pengelolaan wakaf uang melalui UU No. 41 tahun 2004 merupakan sarana rekayasa sosial, untuk melakukan perubahan-perubahan pemikiran, sikap dan perilaku umat Islam agar senafas dengan semangat Undang-Undang tersebut. Menurut dasar pertimbangan Fatwa MUI tentang wakaf uang disebutkan bahwa wakaf uang memiliki fleksibilitas dan kemaslahatan besar yang tidak dimiliki oleh benda lain.

${ }^{33}$ Uswatun Hasanah, 2008, Wakaf Produktif untuk Kesejahteraan Sosial dalam Perspektif Hukum Islam di Indonesia, pidato disampikan saat pengukuhan gelar guru besar tanggal 22 April 2009, diakses pada tanggal 27 Oktober 2010.

${ }^{34}$ Direktorat Pemberdayaan Wakaf dan Direktorat Jenderal Bimbingan Masyarakat Islam, Pedoman Pengelolaan Wakaf Uang, (Jakarta), hal. 32. 
Fahmi Medias: Wakaf Produktif...

Untuk mengelola dan mengembangkan wakaf uang dengan baik, dibutuhkan Sumber Daya Insani yang amanah, profesional, berwawsan ekonomi, tekun dan penuh komitmen yang kuat. Oleh karena itu, lembaga wakaf uang mempunyai peran yang sangat strategis demi terwujudnya wakaf produktif di Indonesia, maka dibutuhkan pembinaan terhadap pengelola wakaf, sosialisasi yang terus menerus oleh para akademisi, ulama, praktisi ekonomi syariah, baik melalui seminar, training, ceramah maupun tulisan di media massa.

\section{DAFTAR PUSTAKA}

Agustianto, (2010). Wakaf Uang dan Peningkatan Kesejahteraan Umat (Artikel Zona Ekonomi Islam), di publikasikan pada Agustus, 2010.

Antonio, Muhammad Syafi'I, (2002). “Bank Syari'ah sebagai Pengelola Dana Wakaf” Makalah Workshop Internasional, "Pemberdayaan Ekonomi Umat Melalui Wakaf Produktif”, di Wisma Haji Batam, 7-8 Januari 2002.

Badan Wakaf Indonesia, (2010). Laporan Wakaf Uang Tahun 2010.

Direktorat Jenderal Bimas Islam dan Penyelenggaraan Haji, (2003). Fiqh Wakaf, (Jakarta: Departemen Agama RI).

Direktorat Pemberdayaan Wakaf dan Direktorat Jenderal Bimbingan Masyarakat Islam, (2008). Paradigma Baru Wakaf di Indonesia, (Jakarta: Departemen Agama RI).

Direktorat Pemberdayaan Wakaf dan Direktorat Jenderal Bimbingan Masyarakat Islam, (2008). Pedoman Pengelolaan Wakaf Uang, (Jakarta: Departemen Agama RI).

Djunaidi, Achmad, (2008). Menuju Era Wakaf Produktif, (Depok : Mumtaz Publishing).

Hasan, Tholhah, (2009). "Perkembangan Kebijakan Wakaf di Indonesia", dalam Republika, Rabu, 22 April 2009.

Hasanah, Uswatun. 2008, "Wakaf Produktif untuk Kesejahteraan Sosial dalam Perspektif Hukum Islam di Indonesia", pidato disampikan saat pengukuhan gelar guru besar tanggal 22 April 2009, diakses pada tanggal 27 Oktober 2010.

Imam Muslim, (t.t.), Sahih Muslim (Bandung: Dahlan).

Majelis Ulama Indonesia, Fatwa Tentang Wakaf Uang Tahun 2002.

Al-Mawardi, (1994). al-Hawi al-Kabir, ditahqiq oleh Mahmud Mathraji, (Beirut : Dar al-Fikr).

Nasution, Mustafa Edwin dan Hasanah, Uswatun (Eds.), 2005, Wakaf Uang Inovasi Finansial Islam, Peluang dan Tantangan dalam Mewujudkan Kesejahteraan Umat (Jakarta: PKTTI-UI).

Rahardjo, Satjipto, (1986). Hukum dan Masyarakat (Bandung: Angkasa).

Sukandi, M. Sjarief, (t.t.), Tarjamah Bulughul Maram, (Bandung: PT. Al-Maarif).

Tabung Wakaf Indonesia, (2010). Laporan Keuangan Tahun 2001-2009 
Fahmi Medias: Wakaf Produktif...

Wadjdy, Farid, (2008). Wakaf dan Kesejahteraan Umat (Filantropi Islam yang Hampir Terlupakan), (Yogyakarta : Pustaka Pelajar).

Yusuf, Muhammad, (2009). Pemberdayaan Wakaf Produktif Untuk Pemberdayaan Ekonomi Umat, (Semarang: Badan Wakaf Nusantara). 